\begin{tabular}{|c|c|c|c|c|c|c|}
\hline \multirow{4}{*}{ Impact Factor: } & ISRA (India) & $=3.117$ & SIS (USA) & $=0.912$ & ICV (Poland) & $=6.630$ \\
\hline & ISI (Dubai, UAE & $=0.829$ & РИНЦ (Russia & $=0.156$ & PIF (India) & $=1.940$ \\
\hline & GIF (Australia) & $=0.564$ & ESJI (KZ) & $=8.716$ & IBI (India) & $=4.260$ \\
\hline & JIF & $=1.500$ & SJIF (Morocco & $=5.667$ & OAJI (USA) & $=0.350$ \\
\hline
\end{tabular}

\section{SOI: $1.1 /$ TAS DOI: $10.15863 /$ TAS International Scientific Journal Theoretical \& Applied Science}

p-ISSN: 2308-4944 (print) e-ISSN: 2409-0085 (online)

Year: 2019 Issue: $06 \quad$ Volume: 74

Published: 14.06 .2019 http://T-Science.org
QR - Issue

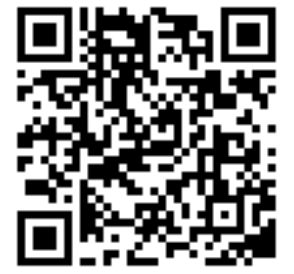

QR - Article

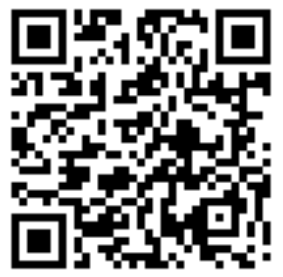

Rano Rakhmatulloevna Kasimova Bukhara State University $\mathrm{PhD}$ in philological sciences, Department of English Literature $\underline{\text { ranokasimova77@mail.ru }}$

Akmal Raupovich Ziyadullayev Bukhara Regional Centre for Retraining Public School Teachers

an English Language Teacher Trainer, Methodology of Teaching Languages Department ziyodullayevakmal@mail.ru

Aziza Akmalovna Ziyadullayeva Bukhara State University a student of Foreign Languages Faculty

\title{
COMPARISON OF CEREMONIES AND LEGENDS ASSOCIATED WITH THE BELIEF IN REVERENCE FOR WATER
}

Abstract: Cult water and reverence for water of the nation become a basis of legends and ceremonies. One of the wide-spread ceremonies is called Rain calling. This ceremony is usually held when people felt need of rain for the crop. A rain fertility ceremony drums and dance of Venda people in South Africa, the Tradition of Cat Procession, the Rocket Festival and the Phi Ta Khon Festival show the same motif and purpose. Rain calling and rituals of it may differ in accordance with the geographical location.

This article, initially, describes and focuses on the ceremonies that have been celebrated by the Uzbeks, Venda people, Thai people, and others. The ritual and songs performed in them will also be referred. Views of the scientists and ethnographers worked on this subject will be evaluated. Later on, classification of the functions of water depicted in the legends of folklore works and their traces in modern literature will be analyzed as well.

Key words: folklore, legends, modern literature.

Language: English

Citation: Kasimova, R. R., Ziyadullayev, A. R., \& Ziyadullayeva, A. A. (2019). Comparison of ceremonies and legends associated with the belief in reverence for water. ISJ Theoretical \& Applied Science, 06 (74), $120-124$.

Soi: http://s-o-i.org/1.1/TAS-06-74-10 Doi: crossef https://dx.doi.org/10.15863/TAS.2019.06.74.10

\section{Introduction}

The ceremony of Rain Calling has been celebrated by our nation since old times. It is one of the ceremonies of spring and it is so-called because it was marked only in a certain season - when it was drought in spring, that's why it is included in the seasonal ceremonies. The Rain Calling ceremony, which shows the reverence for water, was held before beginning the work in the field by peasants. This ceremony exists among lots of nations. Though it differs from one another in every nation all of them are bound on a single purpose, as Marilyn Petersen ${ }^{1}$ writes in her book "A Treasury of Uzbek Legends and Lore": "It is all based on the same theme, the need of and reverence for water (Petersen 2000, 140). It was held while our ancestors were in need of rain and when the harvest was damaged. According to archeologists, the origin of this ceremony dates back as far as the neolithic period and the Bronze Age. Because in the past people held this ceremony by the means of stone jada. It was the first appearance of Rain Calling and as the other model of it there appeared the ceremony of Sust xotin.

\section{Materials and Methods}

The famous Uzbek folklorist B. Sarimsakov informing about the ceremony of Rain Calling, gave the fact that its history was ancient and it's called 


\begin{tabular}{|c|c|c|c|c|c|c|}
\hline \multirow{4}{*}{ Impact Factor: } & ISRA (India) & $=3.117$ & SIS (USA) & $=0.912$ & ICV (Poland) & $=6.630$ \\
\hline & ISI (Dubai, UAI & $=0.829$ & РИНЦ (Russia & $=0.156$ & PIF (India) & $=1.940$ \\
\hline & GIF (Australia) & $=0.564$ & ESJI (KZ) & $=8.716$ & IBI (India) & $=4.260$ \\
\hline & JIF & $=1.500$ & SJIF (Morocco & $=5.667$ & OAJI (USA) & $=0.350$ \\
\hline
\end{tabular}

variously in different places, for instance, in Bukhara, in the districts of Karakul and Olot it is called as Chala xotin [premature woman], among turkmens as Suyut xotin, among tadjiks as Sust momo or Ashaglen (see Sarimsakov 1986, 65).

In the book of Marilyn Petersen is said:

The Balkan people of Eastern Europe had a ceremony called Peperuda [butterfly]. Girls would gather together and one of them would be chosen to represent Peperuda. She was decorated with green leaves and branches. The girls would sing songs around the butterfly as they would go from one house to the next asking God to give them rain. When they would stop at a house, the host would entertain them with sweets and water. In Serbia they had somewhat the same celebration, but the girls surrounding the butterfly would visit the cemetery and ask for support from their ancient ancestors. As they did this, they would pour water on the graves (Petersen 2000, 140).

The extract shows that the ceremony of rain calling has been spread among Eastern European Balkan people and Siberians, whereas the latter information indicates that the same ceremony is held in different regions of Germany, the Caucuses, Central Europe, among the nations of Africa, Asia, and Australia, and Tibet:

In different regions of Germany, boys would be dressed as a water bird. Sometimes the boys would make the water bird out of branches and leaves from a marsh. Then they would carry it out into the streets. The boy who carried the bird would be treated with water. In the Caucuses they would pour water on a man who was made up in the image of the God of rain. They would go from one house to the next singing songs, and were given gifts of food. In Central Europe girls would pull plows through water against the current, or build a dam on a dry river bed. Among the nations of Africa, Asia, and Australia the people would pour water into a stone, or sink the stone in the water. In Tibet the ceremony of calling water was presided over by a Shaman, who would read from a secret book and sprinkle water on a mirror, and the women would walk around the temple with the writings of Buddha on their backs (Petersen 2000, 140).

The ceremony of calling water differs with the local elements as entertaining the girls with sweets and water; pouring water on the graves of the ancestors; treating the boy who carried the bird with water; pour water on a man who was made up in the image of the God of rain; pull plows through water against the current, or build a dam on a dry river bed; pour water into a stone, or sink the stone in the water; ceremony presided over by a Shaman, who would read from a secret book and sprinkle water on a mirror, and the women would walk around the temple and etc. The main participants are girls (Eastern European Balkan people and Siberians, Central Europe), boys (Germany, the Caucuses), and in some parts both women and men (Africa, Asia, Australia, Tibet) throughout the world. There is a rain fertility ceremony drums and dance of Venda people in South Africa (Zimbabwe), where the whole nation takes part. A girl is chosen as an intermediary to talk with her ancestors, who send their wish to God. The most amazing is the tradition of "Cat Procession" of Thai people. A cat in a thinly woven bamboo basket is carried in a procession to pray for rain, which makes this tradition different from other Rain calling ceremonies. In "Thai Tradition and Festivals", Dararai writes:

A selected beautiful female cat is put into a thinly woven bamboo basket. The colourfully dressed farmers in a village will form a procession to parade the cat around the village. When walking, they will joyfully dance and sing a song with the lyrics asking for a rainfall enough for feeding their crops. The procession will pass from one house to another. Villagers staying in their houses when hearing the approaching procession will prepare a bowl of water and then splash it on the cat while the members of the procession will express their gladness as if it were really raining and say,

"Rain is falling. Rain is falling. A lot of rainfall. Our rice fields and the grass are all green now"2.

The Uzbek ceremony Sust xotin is different in forms from region to region. B.Sarimsakov pointed four versions and M.Djurayev pointed six versions of the ceremony and commented on all of them. But the common side of the ceremony is that it is held by women. According to M.Petersen in Uzbekistan, it was mainly the women, who were the rain callers. In the regions of Navoi and Bukhara the rain callers made up puppets. They would go to each house singing songs.

The translation of the Uzbek poem of "Rain callers" shows the skillfulness of the author. She tried to keep both meaning and rhyme of the poem in the translation. The English translation of the poem given next to Uzbek version ${ }^{3}$ helps readers to catch the meaning easily.

The ponds have all dried up,

No fish there remain.

Come, granny Thunder,

We are, from thirst, in pain.

I wanted to plant millet,

But my color became yellowish.

Come, Granny rain, murmuring,

So satisfying eating fish.

The English teacher, for whom folklore has always been of special interest, decided to compile a collection of folklore translated into English and this work revealed her shadowed abilities (in prose and poetry translation). The poem below shows how she 


\begin{tabular}{|c|c|c|c|c|c|c|}
\hline \multirow{4}{*}{ Impact Factor: } & ISRA (India) & $=3.117$ & SIS (USA) & $=0.912$ & ICV (Poland) & $=6.630$ \\
\hline & ISI (Dubai, UAI & $=0.829$ & РИНЦ (Russia & $=0.156$ & PIF (India) & $=1.940$ \\
\hline & GIF (Australia) & $=0.564$ & ESJI (KZ) & $=8.716$ & IBI (India) & $=4.260$ \\
\hline & JIF & $=1.500$ & SJIF (Morocco & $=5.667$ & OAJI (USA) & $=0.350$ \\
\hline
\end{tabular}

skillfully translated the poem remaining ethnographisms, i.e. the words connected with mentality of Uzbek nation in the translation:

They read from the Hadithes

The leaves from trees fall.

Torn from their boughs,

Come dear rain, come to call ${ }^{4}$.

Indeed, information and the poems about the Uzbek ceremony Sust xotin given by the author are true. B.Sarimsakov, a well-known scientist, wrote the same information as well. He says that at the appointed day more than ten women walk through the village carrying a doll worn with clothes of an old woman and enter every house urging the people to sing the song concerning rain. M. Petersen included in her book various names of Sust xotin and translated them into English. Susthoten is translated as the women without energy and Suvhoten as the women of the water. In fact, Sust xotin is derived from the name of one of the Gods of water Tishtriya, described in Avesto, at first it was as Tishtriy, Tushtr, Sustr and at last it got the name of Sust xotin (Sarimsakov 1986, $65)$. that:

Consequences of rain calling is explained like

The owners of the houses would give them wheat or sprinkle them with water. The rain callers made Halisa and Halim $^{5}$ from the wheat that was given to them, and distributed it among the people. The hard work of the rain callers, thirst, and the aspirations of people almost certainly would bring the rain. We admire the highest skill of our ancestors.

Legends revealing the functions of water

Water is described as means of life in the myths, legends and fairy tales typical to folklore. Even world of water is depicted as the mysterious world. In ancient times people considered water as the magic world for passing from one world into another, cleaning up one's act, devoting him eternal life. One of the ancient motifs connected with the cult of water became a basis of origin of the legend about an ascetic [saint] Khodja Ubbon. The so called place is located at about 40 kilometers to the south-west of Bukhara city. This place is famous for its curative water well. The cemetery of Khodja Ubbon is included into the monuments of an ancient culture. Information about the cemetery is observed in the travel book of A. Burnes "Travels into Bokhara" firstly. He gave some facts about the coins and ancient relics of the kings lived in olden times. It was defined that these coins belonged to the kingdoms of III-I centuries B.C (Burnes 1839,vol.II, 455-473).

Narzulla Yuldashev, who had deeply investigated the cemeteries of Bukhara saints and the history of these spots, wrote about the origin of the legend about Khodja Ubbon cemetery: Once upon a time there lived a king whose son caught infectious disease leprosy. Being ashamed of their son's illness parents left him in the desert which is called Khodja Ubbon cemetery nowadays. The boy felt exhausted and thirst in scorching hot. Fortunately with the order of God there appeared Khodja Ubbon and asked the fellow the reason of his being there. King's son told a story of himself. Having heard that Khodja Ubbon ascended the highest hill and as soon as he stuck his javelin into the peak, there appeared a spring. Khodja Ubbon told the boy to drink water of that spring. The young fellow did what he had been told and soon recovered.

It is evident that water is one of the main sources for recovering from the illness. On one hand legends show the curative peculiarities of water, on the other hand the beliefs of rescuing people from disaster exist. In some facts Khodja Ubbon is given in the form of Khubbi and is used for the latter reason. Legends about Khoresm Khubbi indicate that the son of Hakim is a person who amused people with his deeds.

They say that Hakim had three sons; his youngest sons' name was Khubbihodja. Two older sons followed their father and learned religious sciences, but the last one liked to ride the horse and go hunting. Father was upset and angry with his son that he did not follow him. Later Khubbi started to astonish people.

Once Khubbi's father called him three times. After the first calling he started for the road, during the second one he was busy with rescuing suffered people. In the third call he appeared in front of his father. Father got angry with his son's deeds and forced him to leave Khorezm. Khubbi had parted with his father and disappeared.

As you see Khubbi was depicted as a performer of many miracles related to the sea in this legend. So we can say that Khodja Ubbon was created with the help of the imagination and the beliefs of people and always regarded as a mythical hero.

Chashmai Ayub Mausoleum and Legends

One of the wells situated in Bukhara is called Chashmai Ayub which means spring of Ayub. The water of this well is also famous for its curative function. People, who know about that function come and drink water of this well with a good intention. So many versions of the legend about Chashmai Ayub are spread among the nation. Water is shown possessing magic power which can destroy everything that humankind has got. But the end of the legend gives information about the cure for illness.

The blessed Ayub had 14 children and was very wealthy. He was so rich that he didn't know the amount of his property. Being deprived of his children and wealth he was deprived of his health as well. The worms began eating his body. Allah had ordered worms not to eat Ayub's heart and tongue. Because he remembered Him with his heart and repeated His name with his tongue. All the relatives 


\begin{tabular}{|c|c|c|c|c|c|c|}
\hline \multirow{4}{*}{ Impact Factor: } & ISRA (India) & $=3.117$ & SIS (USA) & $=0.912$ & ICV (Poland) & $=6.630$ \\
\hline & ISI (Dubai, UAE & $=0.829$ & РИНЦ (Russia & $=0.156$ & PIF (India) & $=1.940$ \\
\hline & GIF (Australia) & $=0.564$ & ESJI (KZ) & $=8.716$ & IBI (India) & $=4.260$ \\
\hline & JIF & $=1.500$ & SJIF (Morocce & $=5.667$ & OAJI (USA) & $=0.350$ \\
\hline
\end{tabular}

turned away from Ayub even two of his wives out of three abandoned him. People made Ayub leave the city. After some period the worms began to leave one by one but while he was taking the worms and put them again in their places there came revelation not to put them back on his body, because they had already done their duty. He beat his foot on the ground from the place where he was sitting and with the power of Allah there appeared a spring. When he washed up in the water of that spring one of the worms dropped into the water and turned into a leech, and the other one went up to the mulberry tree and turned into a silk worm. The blessed Ayub regained his health.

That hill still exists and has become cemetery of Ayub. Spring water is the treatment for any wound. The people who keep the silk worm take water from this spring and pour on the worms when worms begin to weave cocoon. Old people wish the patience of Ayub to those who are in difficulty.

Another version of the legend about Chashmai Ayub Mausoleum is cited in the book "Bukhara. The city and the legends":

On the place of modern mausoleum, as the legend suggests, there used to be a desert. Its inhabitants had suffered from the lack of water; they had prayed to God to send them at least some water. In response to these prayers, Saint Job [Ayub] had appeared in front of poor people and hit the ground with his magic staff. Sudden appearance of a well had astonished the people by its vivifying spring and its crystal clear water. It is commonly believed that the water still keeps its clearness and herbal power (Bukhara, trans. M.Muzafarova (T.:Davr Nashriyoti,2010), 14).

So, reverence for water and beliefs connected with the cult of water have deep roots in the works of folklore. But in some works of modern literature the theme of water is also been treated. Abdulla Aripov's dramatic epic poem "Way to Paradise" (Jannatga yo $l$ ) repeats the motif of water. While rescuing a girl from the disaster a fellow drowns and dies. So, water became the means of passing from transitive world to eternal one (Nizomova 2013, 93).

\section{Conclusion}

Attempting to clarify the functions of water described in the legends of Khodja Ubbon, Spring of Ayub, in the ceremony of Rain Calling, it became obvious that water and rain have been compared to wealth from ancient times and became a basis of peculiar ceremonies and customs to be formed. Furthermore, ceremonies connected with the belief in water and belief of our ancestors to nature attracts scientists all over the world.

In general, it can be said that peoples' belief of revering for water exists not only in the works of folklore but also has its traces in the works of modern literature, which causes admiration of the treasure of Uzbek convictions about water.

\section{NOTES}

1. Dararai, in his article "Thai Tradition and Festivals" informs that due to the climate of the north, northeast and the central regions of Thailand, which is dry in the hot and the cool seasons, ceremonies of praying for rainfall are held in these regions. Stories and legends about three such important ceremonies, the Tradition of Cat Procession, the Rocket Festival and the Phi Ta Khon Festival, are presented as well.

2. Original Uzbek version of the poem:

Quriganmish gul hovuz.

Baliqlardan biror iz

Guldur-momo kelsang-chi

Tashnalab bo `ldik ojiz

Istardim ekmak tariq,

Ranglarim bo `ldi sariq.

Shaldir-momo kelsang-chi

Savobdir yemak baliq

3. Hadis: (Arabic) hadith, the traditions or records of the words and deeds of the Prophet Muhammad

4. Halim: (Arabic) a dish made out of boiled wheat and meat. Halisa is another name of the traditional meal Halim spread in Bukhara region, which differs with the cooking process.

\section{References:}

1. (n.d.). Academic e-Tutor Longman Advanced American Dictionary. Retrieved 2019, from www.PearsonLongman

2. (2010). Bukhara. The city and the legends, trans.M.Muzafarova. Tashkent: Davr Nashriyoti.
3. Burnes, A. (1839). Travels into Bokhara, being an account of journey from India to Cabool, Tartary and Persia in the years 1831. 1832 and 1833. London, vol.II.

4. (n.d.). Dararai, "Thai Tradition and Festivals". Retrieved 2019, from 


\begin{tabular}{|c|c|c|c|c|c|c|}
\hline \multirow{4}{*}{ Impact Factor: } & ISRA (India) & $=3.117$ & SIS (USA) & $=0.912$ & ICV (Poland) & $=6.630$ \\
\hline & ISI (Dubai, UAI & $=0.829$ & РИНЦ (Russia & $=0.156$ & PIF (India) & $=1.940$ \\
\hline & GIF (Australia) & $=0.564$ & ESJI (KZ) & $=8.716$ & IBI (India) & $=4.260$ \\
\hline & JIF & $=1.500$ & SJIF (Morocco & $=5.667$ & OAJI (USA) & $=0.350$ \\
\hline
\end{tabular}

https://www.youtube.com/watch?v

=p9muWywQLYw

5. (2005). Dirks William. Uzbek - English Dictionary. Central Asian Heritage Group.

6. Juraev, M., \& Saidova, R. (2002). Bukhoro afsonalari [Legends of Bukhara]. Tashkent: Xalq Merosi Nashriyoti.

7. (2002). Macmillan English Dictionary. Macmillan Publishers Limited.

8. Nizamova, S. (2013). Zamonaviy she'riyatda suv bilan bog 'liq qadimiy tushunchalar talqini [Interpretation of ancient beliefs connected with water in modern poetry], Filologiya masalalari, no.6. Tashkent: Fan.

9. Petersen, M. (2000). Treasury of Uzbek Legends and Lore. Tashkent: Qatortol - Kamolot.

10. (n.d.). Rain fertility ceremony drums and dance of Venda people (South Africa/Zimbabwe). Retrieved 2019, from https://www.youtube.com/watch?v=p9muWyw QLYw

11. Sarimsakov, B. (1986). O`zbek marosim folklori [Folklore of Uzbek ceremonies]. Tashkent: Fan.

12. Yuldashev, N. (1997). Buxoro avliyolarining tarixi [History of Bukhara Saints]. Bukhara. 